\begin{tabular}{|c|c|c|}
\hline 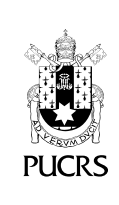 & $\begin{array}{l}\text { ESCOLA DE } \\
\text { HUMANIDADES }\end{array}$ & $\begin{array}{l}\text { Revista de Cultura e Literaturas de Lingua Portuguesa } \\
\text { Navegações, Porto Alegre, v. 14, n. 2, p. 1-17, jul.-dez. } 2021 \\
\text { e-ISSN: 1983-4276 ISSN-L: 1982-8527 }\end{array}$ \\
\hline def $h t t p: / / d x$ & org/10.15448/1983-4276.2021.2.41611 & \\
\hline
\end{tabular}

SEÇÃO: ENSAIOS

\title{
Dialética, subjetividades e história, ou uma leitura de A lata de lixo da história de Roberto Schwarz
}

\author{
Dialectics, subjectivities and history, or a reading of A lata de lixo da história by Roberto \\ Schwarz
}

\section{Fernando Cambauva \\ Breda $^{1}$}

orcid.org/0000-0003-1694-1561

fcbreda59@gmail.com

Recebido em: 24 ago. 2021. Aprovado em: 14 out. 2021. Publicado em: 16 dez. 2021.
Resumo: Escrita no fim dos anos 1960, a peça A lata de lixo da história se insere num momento da maior importância da vida social brasileira e, igualmente, da de seu autor, Roberto Schwarz. Seu contexto de produção foi, do ponto de vista nacional, de acirramento repressivo da ditadura civil-militar brasileira e, do ponto de vista pessoal de Schwarz, de sedimentação de uma virada critica bastante significativa. Nesse sentido, é interesse deste trabalho analisar a peça à luz das transformações pelas quais passava o país em articulação com uma certa sedimentação de derrota histórica da ideia de formação nacional que ia se afigurando ao jovem Roberto Schwarz. No centro de nossa análise está a noção de dialética, tão central ao ponto de vista materialista de Schwarz. A despeito de variados estudos que têm sido feitos a respeito de sua obra, pouco tem se discutido, a não ser em chave celebratória, sobre o modo como a dialética se opera em seu trabalho. Refiro-me, sobretudo, ao modo como a luta de classes em sua acepção brasileira é figurada pelo critico, levando em conta, sobretudo, sua visão sobre a margem de arbitrio praticamente absoluto das elites brasileiras e uma noção algo estática das relações escravistas. A escolha pela peça se deu justamente porque ela cristaliza uma convivência de temporalidades contraditórias que revela um certo sentimento de época diante do que significava a ascensão dos militares ao poder em 1964, bem como elucida aspectos contraditórios da produção schwarziana pouco comentados em sua fortuna crítica.

Palavras-chave: Roberto Schwarz. Machado de Assis. Brecht. Dialética. Escravismo.

Abstract: The play A lata de lixo da história was written in the late 1960s, a moment of great importance in Brazilian social life as of its author, Roberto Schwarz. Its production context was, from a national point of view, one of repressive intensification of the Brazilian civil-military dictatorship and, from Schwarz's personal point of view, of sedimentation of a very significant critical turn in his work. In this sense, we aim to analyze the play looking at it articulately with the transformations the country was going through and a sedimentation of an end-feeling to the idea of national formation to the young Roberto Schwarz. At the heart of our analysis is the notion of dialectic, so central to Schwarz's materialist point of view. Despite the various studies that have been done about his work, little has been discussed about the way in which dialectics operates in his work, except in a celebratory way. I am referring, above all, to the way in which the class struggle in its Brazilian sense is portrayed by the critic, taking into account his view on the practically absolute margin of will of the Brazilian elites and a somewhat static notion of slave relationships. The play was chosen precisely because it crystallizes a coexistence of contradictory temporalities that reveals a certain generational sense with what the military's rise to power in 1964 meant, as well as it elucidates contradictory aspects of Schwarzian production that have been little commented on in his critical fortune.

Keywords: Roberto Schwarz. Machado de Assis. Brecht. Dialectic. Slavery. 


\section{Introdução}

O nome de Roberto Schwarz habita o debate intelectual brasileiro há praticamente meio século: pelo menos desde a publicação de seu ensaio "Cultura e política: 1964-1969" - que saiu primeiro em francês na revista Les Temps Modernes (1970) e depois foi incluido no livro O pai de familia e outros estudos (1978) -, quando as polêmicas com Caetano Veloso, a afiada análise de conjuntura e as críticas ao espetáculo "Opinião" e ao Teatro Oficina fizeram algum verão no Brasil. Anos depois, a importância do crítico se consolidaria definitivamente por conta de seus estudos sobre Machado de Assis, publicados em dois livros: Ao vencedor as batatas de 1977 e Um mestre na periferia do capitalismo de 1990.

A despeito das variações históricas de seu trabalho, é possivel dividir sua trajetória em dois momentos fundamentais: o trabalho anterior à decantação dos sentidos históricos que Schwarz imprime ao golpe civil-militar de 1964 e o posterior a tal interpretação. Em outras palavras, pode-se dizer que os sentidos que ele tira do golpe de 1964 operam uma virada em seu trabalho, alçando três coordenadas fundamentais a primeiro plano. Atuando como espécie de vetor matricial, a incorporação da matéria histórica brasileira como eixo analítico é a mais fundamental de todas, inclusive da qual resultam as demais, no caso: o abandono de uma noção lukacsiana de realismo (profundamente marcada por uma noção estética normativa e ancorada, por sua vez, em uma concepção progressiva do tempo histórico ${ }^{2}$ e a assunção da derrota histórica da versão democrática do nacional-desenvolvimentismo diante do que ascendeu ao poder com o golpe de 1964. Todas com consequências diretamente implicadas em sua interpretação do Brasil, dos sentidos da luta de classes e do funcionamento das ideologias prestigiosas do centro do capitalismo na periferia do sistema.

Em linhas gerais, tal guinada pode também ser pensada como uma incorporação da ideia de "formação do Brasil" enquanto princípio metodológico"3 (ARANTES, 1997, p. 20), mas realizada em chave negativa, na qual seu horizonte seria a própria impossibilidade de integração nacional. ${ }^{4}$

Mesmo que ainda em 1964 Schwarz tenha publicado uma critica ao romance $O$ amanuense Belmiro de Cyro do Anjos, em que já esboçava a formalização de um certo tempo histórico brasileiro de combinações antitéticas que pareciam se acomodar sem superação, a formalização dessa temporalidade só se tornaria cristalina em 1977 quando da publicação de Ao vencedor as batatas, no qual a assim chamada matéria histórica brasileira (e a irrealização sistemática da superação de seus impasses) passa a ser seu assunto fundamental.

No artigo de 1964, o modo como tal matéria se afigurava a Schwarz não tinha a mesma radicalidade negativa com que tomaria corpo em 1977. De modo que quando o crítico a recompõe a partir de um Machado relido pós-64, a substância que passava a dar o tom dessa matéria passava também a demandar uma alteração radical do próprio método crítico de Schwarz; isto é, sua noção de Realismo tinha de se haver com uma temporalidade brasileira bastante singular que não se ajustava ao modelo lukacsiano, dando lugar, no caso, a uma nova noção de realismo, que perdia em normatividade o que ganhava em

\footnotetext{
2 Na boa formulação de Maurício Reimberg, tratava-se de uma "espera schwarziana, saturada de expectativas, lem que] o futuro assumia por vezes um caráter de evidência progressista. E isso nutre um modo especifico de subjetivação, inscrito nessa dinâmica histórica orientada e cumulativa (que, até o golpe, era tensionada pela hipótese real de superação do subdesenvolvimento)" (REIMBERG, 2019, p. 73).

3 A noção de "formação enquanto princípio metodológico" está baseada nas formulações de Paulo Arantes, Maria Arminda do Nascimento Arruda e Leandro Villarino sobre a ideia de formação. Levando em conta que o conceito de formação diria respeito a um "modo de indagar-se sobre a viabilidade da realização da sociedade moderna entre nós" (ARRUDA; VILLARINO, 2016, p. 3), pautada no "ideal europeu de civilização relativamente integrada" (ARANTES, 1997, p. 12) a noção de sistema literário pode ser encarada como uma espécie fórmula metodológica que permite pensar de maneira sistemática a força cumulativa dos processos de consolidação e aproximação de um ideal europeu de civilização relativamente integrada. De modo que assim, a ideia de sistema literário convertia-se em método tanto de enfrentamento ao travejamento sociológico dos conceitos e instituições europeias na vida brasileira, como de interpretação e sondagem da matéria histórica brasileira a partir do desvio em relação aos padrões europeu.

4 No que se configura como uma aproximação com o modelo crítico de seu mestre. Antonio Candido, mediada, é claro, por um período histórico de rebaixamento de expectativas. De todo modo, essa mudança de horizonte não alteraria o quadro de uma similitude metodológica entre seus trabalhos.
} 
negatividade (ou realismo, com " $r$ " minúsculo).

"Cultura e política", por exemplo, finalizado em 1970, já se distingue de escritos anteriores pela centralidade dessa matéria histórica no trato com as obras artísticas do período. Ocorre que ainda aí há uma espécie de principio-esperança na possibilidade de "virada do jogo"; figurada, por sua vez, de maneira (nem tão) cifrada no encerramento do texto, quando evoca o movimento político do padre Nando do romance Quarup, cuja direção ao povo encerrava-se em capítulo posterior, externo (e armado) ao romance. ${ }^{5}$ Não por acaso, a crítica à Tropicália deste ensaio guarda ainda relação com a noção lukacsiana de realismo, em que nada pode ser pior do que uma obra em que a História figure antes como "destino nacional, que dura desde os inícios" (SCHWARZ, 1978, p. 91) do que como local de disputas. Quanto a isso, a nota reparadora de 1978 é bastante elucidativa de um certo rebaixamento em seu horizonte de expectativas - e, com isso, também um afastamento da noção de temporalidade ascendente:

As páginas que seguem foram escritas entre 1969 e 1970. No principal, como o leitor facilmente notará, o seu prognóstico estava errado, o que não as recomenda. Do resto, acredito - até segunda ordem - que alguma coisa se aproveita. A tentação de reescrever as passagens que a realidade e os anos desmentiram naturalmente existe. Mas para que substituir os equivocos daquela época pelas opiniões de hoje, que podem não estar menos equivocadas? Elas por elas, o equivoco dos contemporâneos é sempre mais vivo. Sobretudo porque a análise social no caso tinha menos intenção de ciência que de reter e explicar uma experiência feita, entre pessoal e de geração, do momento histórico. Era antes a tentativa de assumir literariamente, na medida de minhas forças, a atualidade de então. Assim, quando se diz 'agora', são observações, erros e alternativas daqueles anos que têm a palavra. O leitor verá que o tempo passou e não passou (SCHWARZ, 1978, p. 61, grifo nosso)
Nesse sentido, portanto, é somente na segunda metade da década de 1970 que uma espécie de visão pessimista (ou negativa que seja) quanto ao que significa a modernidade brasileira se cristalizou em seu trabalho. Ou seja, a partir de seu contato com a obra machadiana, em que o objeto de estudo parecia confirmar a visada negativa do crítico e vice-versa.

Há, porém, no meio disso tudo uma parada pouco comentada rumo ao destino final "Estação Desesperança": a chanchada A lata de lixo da história, escrita por volta de 1968, justamente o ano em que Schwarz passava aos estudos de Machado de Assis com vistas a um doutorado. Ainda que somente nove anos depois é que ficaria evidente que o pessimismo parodiante do Bruxo do Cosme Velho se encaixaria como uma luva à mão ferina do crítico em transe, ${ }^{6}$ muito do que apenas anos mais tarde se tornaria marca de seu trabalho acadêmico já se esboça nesta peça - inclusive em elementos contraditórios pouco discutidos por seus comentadores.

\section{Um drama}

A lata de lixo da história é a única produção dramática do autor que foi publicada. Os demais trabalhos de Schwarz no campo artístico são os poemas publicados nos livros Pássaro na gaveta (1959) e Corações veteranos (1974).

Como bem recorda Ricardo Musse a respeito dos versos, o mais provável é que "as novas gerações, inclusive os discipulos mais recentes do professor e crítico literário Roberto Schwarz, desconhecem a obra poética dele" (MUSSE, [2017]). Seja pela linguagem surpreendente e contrastante com a seriedade uspiana do velho marxista, seja pela pouca circulação comercial,

\footnotetext{
5 "A cultura é aliada natural da revolução, mas esta não será feita para ela e muito menos para os intelectuais. É feita, primariamente a fim de expropriar os meios de produção e garantir trabalho e sobrevivência digna aos milhões e milhões de homens que vivem na miséria. Que interesse terá a revolução nos intelectuais de esquerda, que eram muito mais anti-capitalistas elitários que propriamente socialistas? Deverão transformar-se, reformular as suas razões, que entretanto haviam feito deles aliados dela. A História não é uma velhinha benigna. Uma figura tradicional da literatura brasileira deste século é o 'fazendeiro do ar': o homem que vem da propriedade rural para a cidade, onde recorda, analisa e critica, em prosa e verso, o contato com a terra, com a familia, com a tradição e com o povo, que o latifúndio lhe possibilitara. É a literatura da decadência rural. Em Quarup. o romance ideologicamente mais representativo para a intelectualidade de esquerda recente, o itinerário é o oposto: um intelectual, no caso um padre, viaja geográfica e socialmente o país, despe-se de sua profissão e posição social, à procura do povo, em cuja luta irá se integrar - com sabedoria literária - num capitulo posterior ao último do livro" (SCHWARZ, 1978, p. 92).

6 O trabalho crítico de Schwarz no período foi justamente marcado pela coexistência da "lógica de certa temporalidade cumulativa e ascendente, que se quer apoiada no conflito e na consciência coletiva, e a verificação de um presente que parece enredado numa reprodução ampliada de si mesmo, desprovido da dialética forte de oposições entre indivíduo e sociedade" (REIMBERG, 2019, p. 10).
} 
fato é que seus versos não gozam da mesma popularidade dos de seus colegas de geração, como Cacaso e Francisco Alvim. ${ }^{7}$

Seja como for, tendo sua atividade artística circulado muito menos do que sua produção crítica, não é sem razão levar em conta que a importância de Schwarz na vida cultural brasileira seja, sobretudo, vinculada à sua atuação enquanto crítico da cultura. Consideração que, por sua vez, não desfaz o interesse de suas produções artísticas.

No que diz respeito à peça, o interesse ganha relevo se levarmos em conta que ela se insere num momento fundamental na vida do crítico em que muitos aspectos que se tornariam marcas de seu trabalho se entrecruzavam naquele instante, ainda que todos em processo de "sedimentação intelectual":

a) a já mencionada incorporação metodológica da ideia de "formação nacional", justo no momento de consideração da própria impossibilidade de sua realização histórica; ${ }^{8}$

b) a formação de uma constelação "contraditória" de referências em Brecht, Lukács, Benjamin e Adorno (SCHWARZ, 2000, p. 14);

c) e, finalmente, o contato com o trabalho de Machado de Assis em que a combinação entre "antigo" e "moderno" fazia figura de problema fundamental.

De forma que, como veremos, alguns dos limiares que o crítico enfrentava em seu ofício ganhava tratamento renovado na pena do dramaturgo, assim como desdobramentos posteriores do primeiro já se apresentam como esboços de movimento nos diálogos e rubricas do segundo.

\section{O que vai para a lata?}

Escrita entre 1968 e 1969, A lata de lixo da história carrega em si o clima de "pastelão macabro" que marcou parte da produção cultural brasileira no periodo. Ou como afirmou seu autor a respeito do processo produtivo, sua escrita teria se dado:

em dezembro de 1968, pouco antes da decretação do Al-5, que afundou o país em anos de terror. [...] A gravidade do momento era brutal, mas ainda assim a grossura dos generais arrancava riso, uma risada algo histérica, em que se misturavam o medo e a angústia (SCHWARZ, [2014C]).

Os alvos de chacota eram evidentes: um certo populismo de esquerda e a "combinação esdrúxula", orquestrada pelo regime militar e pela elite brasileira, de reposição do arcaico para figuração do moderno. Ou ainda, era justamente essa a combinação de temporalidades que passava ao centro dos interesses de Schwarz. Não por acaso, sua leitura posterior de Machado também será uma espécie de exploração "dessa constelação na armação da narrativa machadiana [...] sobre cuja gênese o desfecho de 1964 lançara nova luz" (ARANTES, 1992, p. 59-60).

De modo que a virada crítica que se operava na pena de Schwarz neste momento não era apenas de interesse por um autor radicalmente negativo, nem somente de assunto (no caso, a literatura brasileira): a própria concepção de História do jovem Schwarz ia se alterando conforme ia se afigurando aos seus olhos os sentidos históricos do golpe e da narrativa machadiana, um iluminando o outro reciprocamente. ${ }^{9}$

Simplificando, era como se ao crítico fosse se revelando, a partir do que via no poder e nos escritos machadianos, a existência de uma di-

\footnotetext{
7 Vale notar ainda a esse respeito que o próprio Schwarz "resiste ao esforço coletivo de apagamento de rastros, noticiando, nas notas das inúmeras edições de seus livros, a publicação de Pássaro na gaveta e Corações veteranos" (MUSSE, [2017]).

8 É interessante que também Paulo Emilio Salles Gomes procurou trabalhar no campo artístico quando a ideia de formação do Brasil passava a girar em falso em sua concepção, o que se deu em periodo muito próximo ao de Schwarz e, igualmente, mediado pelo contato com a obra de Machado de Assis. Conforme aponta José Antonio Pasta Jr., a prosa ficcional de Salles Gomes assinalava também, "em epitome, o ajuste de contas do autor com a ideia de formação - central para ele e para toda a sua geração, em cuja mentalidade fora ao mesmo tempo projeto, ideia reguladora e mito fundador. [.... A Paulo Emilio, tudo indica, não mais parecia possivel reiterar simples e anacronicamente o projeto - no entanto irrenunciável. Restar-lhe-ia a alternativa paradoxal de praticá-lo em condições extremas, arriscando lances de resultados imponderáveis, no âmbito estreito da coabitação forçada com tudo que constituia o avesso desse projeto, a todo tempo sujeitando-se a vê-lo convertido em seu contrário" (PASTA, 2015, p.116-117).

9 Também em prefácio à reedição da peça, Schwarz levanta que "o paralelo lelucidativo entre o regime militar e a obra machadiana funcionava como uma via de duas mãos e tinha efeitos retroativos. Não era só o velho Machado que emprestava personagens e situações para falar da repressão em nosso presente. O caminho inverso também valia, sugerindo uma leitura menos convencional do mestre e, por meio dele, do passado brasileiro. O festival de desfaçatez armado por nossas elites logo em seguida ao golpe, com sua salada
} 
mensão estrutural do capitalismo brasileiro que fazia com que um suposto salto desenvolvimentista, capaz de alterar os sentidos da colonização e trazer consigo uma integração cidadã dos "inorgânicos" (para ficarmos nos termos de Caio Prado), fosse sempre interrompido. Assim, a "superação histórica do atraso nacional" deixava de se afigurar como etapa, demonstrando-se antes dado estrutural quase incontornável -pondo em xeque certa noção de realismo cuja realização dependia de uma pintura do mundo ancorada numa noção de tempo progressivo e orientado.

Não surpreende, portanto, que, já em 1970, parte central de suas questões seja a ilusão de parte da esquerda brasileira para com uma burguesia nacional, que poderia industrializar o Brasil e fazer o país dar um "salto adiante". Como se, já ali, para o crítico fosse necessário encerrar de vez qualquer ilusão com essa classe, impedida por motivos estruturais de cumprir as expectativas nacional-desenvolvimentistas e que optaria sempre "por abdicar de uma vez por todas de tentar a hegemonia plena da sociedade, satisfazendo-se com a condição de sócio-menor do capitalismo ocidental" (CARDOSO, 1964. p. 186). De sorte que dentro desse esquema, a superação estrutural de um problema atávico só poderia tomar corpo por meio de uma revolução social - o que naquele momento tomava feição de defesa da luta armada, que também ela deu com os burros n'água, como bem assinalou a nota de 1978.

É aí que retornamos à peça. Sua estrutura formal e seu enredo têm como centro dinâmico justamente a exploração das crises "à brasileira" de uma transição histórica em curso, ou se quisermos, em virtual realização futura. Nesse sentido, a opção estética que toma Schwarz diante da novela de Machado é politizante. Como ele próprio comentou:

o conto [O alienista] é muito político e isso foi pouco notado pela crítica. Tem uma razão literária, ou estrutural se a gente quiser, de organização do conto que explica isso: o elemento organizador da dinâmica do conto são as teorias da loucura do Simão Bacamarte. [...] De modo que o que está no primeiro plano são as teorias da loucura. E o que está no segundo plano são as reações, ou melhor, é o movimento popular - e não só popular, também da elite - contra essas teorias da loucura. Mas isso é um segundo plano. [...] O forte do conto está no entrelaçamento entre as teorias da loucura e a política. [...] O que eu fiz? Eu inverti as precedências: coloquei o movimento social em primeiro plano e tornei as teorias da loucura puramente instrumentais pro movimento geral. Então, de certo modo, foi uma operação de adaptação que procura, na minha opinião, o que é mais forte no Machado e subordinar o outro aspecto (informação verbal). ${ }^{10}$

Ou seja, seu interesse é a politica que subsiste na ficção machadiana. Assim, ao escrever sua peça, a operação artística de Schwarz procurava pôr em cena menos as teorias da loucura ou os impasses históricos mais prováveis a que referenciavam o conto ${ }^{11}$ do que o próprio conflito que ele mesmo vivia naquele momento: a possivel passagem nacional-desenvolvimentista da "colônia à nação" interrompida pelo golpe. Assim, se na narrativa machadiana, os alvos da crítica faziam referências às disputas de poder entre "as quatro instâncias que constroem o mundo Ide Itaguaí e do Brasil Imperial], determinam sua ordem e regulam sua representação: a Igreja, a Ciência, a Câmara de Vereadores e o Povo" (TEXEIRA, 2008, p. 150), na de Schwarz quem entrava na mira eram tipos ideais representativos de uma fração iludida (pelega? ${ }^{12}$ ) da esquerda brasileira,

de modernização, truculência e provincianismo, ensinava a reconhecer aspectos até então recalcados da ironia machadiana. Esta aparecia a uma luz nova, muito mais ferina e politica, de incrivel atualidade. Noutras palavras, as revelações sociais trazidas pelo golpe de 64 desempoeiravam o maior de nossos clássicos" (SCHWARZ, [2014C]).

10 Fala de Roberto Schwarz em evento-debate sobre A lata de lixo da história promovido em 6 de agosto de 2014 na Universidade de São Paulo.

${ }_{11}$ "Consensualmente, admite-se que O Alienista adota o assunto da loucura como instrumento de sátira à ciência do século XIX, mais especificamente ao cientificismo de orientação positivista. Todavia, é possivel supor que a denúncia irônica da ciência e a investigação humorística da loucura exercem função subsidiária em argumento mais abrangente. [...] Pode-se dizer, por conseguinte, que a narrativa se configura como resposta alegórico-humoristica a questões desencadeadas por três séries de eventos que determinam o surgimento de tópicas importantes no repertório cultural do Segundo Reinado: dissidências entre o Estado e a Igreja, postas em evidência pela Questão Religiosa; consolidação da prática psiquiátrica no Brasil, observada a partir da criação do Hospício de D. Pedro Il; e discussão em torno da unidade do Império Brasileiro, motivada, sobretudo, pelas revoltas do Periodo Regencial" (TEIXEIRA, 2008, p. 149-51).

12 O termo "pelego" foi adotado em sua acepção política do uso popular da expressão. Nesse sentido, faz referência a lideranças políticas populares que procuram equalizar posições, supostamente inconciliáveis, entre diferentes frações sociais. Conforme Rodrigues 
figurada no barbeiro Canjica, da elite nacional na figura dos notáveis, e do regime autoritário, com Bacamarte. Resultando, portanto, numa operação formal que não se configura como desacerto artístico, ainda que possa incorrer em certo anacronismo histórico.

De todo modo, tanto ele como seu autor dileto trabalhavam com uma chave comum: a parodização dos agentes históricos envolvidos no conflito. E nesse ponto, um certo problema de forma passa ao centro do trabalho dramático de Schwarz - o qual, a meu ver, ele saberá melhor resolver enquanto crítico: como fazer unidade de sua tradição contraditória?

Como bem notou Fabio Querido, a peça

não esconde a sua intenção brechtiana, mas o tempero machadiano - inspirado em O alienista - acrescentava a dimensão do impasse brasileiro, sob o signo de mais uma rodada de articulação entre o moderno e o "atrasado", entre a norma proclamada e a exceção reiterada. No fim das contas, é como se, já aqui, a voltagem machadiana bloqueasse algo da propensão progressista da forma brechtiana (QUERIDO, 2019, p. 243)

De sorte que é no próprio cruzamento de impossibilidades eletivas entre a estética mudancista brechtiana e a formalização machadiana de uma temporalidade brasileira que "se move para se manter igual" que a peça nos interessa. Como se o machadismo do assunto, não "tolerando" a bechtianidade da forma, conformasse uma antinomia entre forma e conteúdo que talvez seja o aspecto mais revelador desta chanchada.

Buscar inspiração na imagem de um relógio (SÜSSEKIND, 1993) pode nos ajudar a compreender do que se trata tal antinomia e/ou crise formal. Temos, então, um relógio cujos ponteiros têm funcionamentos distintos: um, brasileiro, está praticamente parado no seu estatuto colonial; o outro, o do "capitalismo avançado", andaria em ritmo acelerado. De modo que o funcionamento deste relógio estaria assentado na "incompatibilidade e copresença da inércia e do movimento, do humano e da potência estranha e má, da periferia e do centro, do lugar e das ideias" (TELLES, 2005, p. 123).

Esse descompasso temporal é, pois, justamente, o que faz com que a peça ganhe em sentido histórico e heurístico o que perde em unidade: a movência histórica inerente ao teatro épico brechtiano chegava simplesmente ao Nada da prosa machadiana. Ou ainda, a temporalidade brechtiana em contato com a matéria histórica brasileira é subsumida a uma outra temporalidade cuja marca é um ponteiro que se move sem nunca sair do lugar. O que, claro, não se dá sem consequências.

\section{Brecht eu misturo com Machado}

Poderíamos começar a análise da peça por seu título, afinal, nada mais antimachadiano do que uma lata de lixo da História. Mas deixemos, por ora, isto de lado e passemos à primeira página. Há aí uma rubrica de indicações cenográficas que condensa uma série de questões:

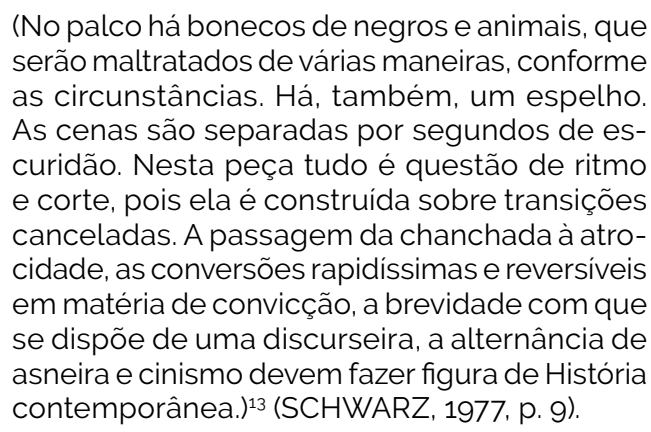

Aqui, algo da leitura posterior de Schwarz funciona como um farol que nos permite compreender o arranjo cênico proposto. Com argúcia, Schwarz-critico soube ver como no romance maduro machadiano se cristalizam literariamente os mecanismos pelos quais a elite brasileira embaralha em seu proveito "independência à dependência, utilidade ao capricho, universalidade

(1968), a origem desta acepção remonta ao periodo varguista, quando líderes sindicais que defendiam os interesses do Ministério do Trabalho assim eram chamados. Em sentido literal, "pelego" é uma peça de couro colocada entre a sela e o lombo do cavalo para gerar maior conforto à cavalgada.

13 Os trechos da peça que serão trabalhados neste artigo pertencem à versão publicada em 1977. A opção pela versão original do texto se deu, por um lado, para evitar anacronismos e, por outro, por considerar que as várias mudanças realizadas na versão de 2014 alteram os sentidos da mesma. Por sinal, a meu ver, muito para além da mera inserção de uma fala feminina, que o próprio autor procurou destacar como uma nova lufada de dialética, uma espécie de balanço sobre junho de 2013 e um acerto de contas com a misoginia, sua e de Machado, da versão anterior. 
às exceções, mérito ao parentesco, igualdade ao privilégio" (SCHWARZ, 2012, p. 19), conciliando a um só tempo uma faceta moderna/prestigiosa lastreada em fundo arcaico/violento, cujo resultado é uma espécie de "desenvolvimento moderno do atraso" (SCHWARZ, 2000, p. 27).

Nesse sentido, a justaposição de surras e espelhos guarda relação direta com um certo comportamento da elite nacional, cuja feição será vista pelo crítico na volubilidade de alguns narradores machadianos. ${ }^{14}$ No mais, as duas coisas (surras e espelhos) em conjunto atuam como recurso cênico que evidencia o narcisismo da elite que se quer ver como portadora das mais belas ideias ao mesmo tempo que espancava seus escravos. Fazendo de tais elementos cênicos uma espécie de formalização de problemas levantados no conto "O espelho" e "A teoria do medalhão", Schwarz em um movimento de condensação artística expressa com didatismo e recursos simples a violência dessa elite que, em Machado, encontra-se velada em plano latente.

Sendo o espancamento o complemento real do espelho, cairia por terra qualquer civilidade, fazendo evidenciar, por exemplo, o lado horripilante de uma figura como Cotrim, cunhado de Brás Cubas, cuidadoso pai de familia, generoso membro de irmandade beneficente e violentamente brutal com os trabalhadores escravizados. Digamos, então, que parte central da crítica posterior de Schwarz à obra de Machado se põe em cena antes mesmo do primeiro diálogo, operada a partir de uma mera rubrica indicando o arranjo cênico.

Também a relação de iluminação recíproca entre o texto machadiano e o golpe militar se coloca já na primeira cena, quando em rubrica fica indicada que "em homenagem à censura muda a peça para outro país" (SCHWARZ, 1977. p. 12), no caso, a Suiça.

Até aqui, contando com o título, estamos no plano da pura dimensão brechtiana da peça, que parece dizer algo como "Itaguaí é aqui e o que está para ser posto em cena diz respeito ao nosso presente e à nossa situação. Vejamos nossas opções históricas à vista".

E o andamento inicial da peça parece mesmo caminhar por esse trilho: quase que um desfile de personagens bufões e histriônicos da elite de Itaguaí. Suas preocupações, em um primeiro momento, dizem respeito ao próprio motivo que vai organizar os conflitos da peça: o que fazer com Bacamarte e seu crescente poder alicerçado em suas teorias da loucura? Ou seja, como lidar com o sistema Bacamarte passando a ser o vetor da organização sociopolítica daquela sociedade?

Enquanto a ciência servia aos propósitos da elite escravista e patriarcal, ela era defendida porque prestigiosa, ainda que fosse desacreditada - como fala um notável, "É político - meus caros - respeitar a ciência, se quisermos que seja científico respeitar a política" (SCHWARZ, 1977. p. 26). No momento em que se volta contra os interesses dessa classe, o prestígio da ciência passa a ser problematizado e mesmo enfrentado pelos notáveis: quando a fome encarceradora do alienista estende-se também aos ricos, a elite se vê diante de um impasse quanto ao que fazer.

Desse ponto em diante, a peça passa, então, a ter como seu centro dinâmico as reações que os arroubos autoritários do sistema Bacamarte engendram. Entram literalmente em cena três possibilidades de mudança social no mundo de Itaguaí: a primeira diz respeito às próprias tentativas de modernização do alienista Simão Bacamarte e suas teorias científicas da loucura. Afinal, diz ele, que sua ciência seria contrária à combinação entre "colonial e moderno", típica dos padres, em favor de uma restauração da clareza. As outras duas articulam-se com a primeira na medida em que são reações a ela: no caso, a revolta reacionária dos notáveis da cidade e um levante popular.

De parte da elite, procura-se uma solução "alta, um entendimento com Bacamarte":

14 "Pelo simples diagrama, a célula elementar do andamento machadiano supõe, em um nivel de abrangência máxima, uma apreciação da cultura burguesa contemporânea, e outra da situação especifica da camada dominante nacional, articuladas na disciplina inexorável e em parte automatizada de um procedimento [a volubilidade], a que o significado histórico deste atrito empresta à vibração singular" (SCHWARZ, 2000, p. 150). 
TERCEIRO ORADOR: Correto. Para questões complexas, soluções complexas. Se cortamos o estipêndio de Bacamarte porque ele não é subornável, parecerá que sobrepomos o nosso interesse ao interesse da ciência. Não é o que nós queremos. Nós queremos que os dois coincidam. Em outras palavras, que a autoridade desinteressada da ciência sustente a autoridade do nosso interesse

PRIMEIRO ORADOR: Tecnicamente, o problema é simples, é de jurisdição. Precisamos estabelecer quem pode e quem não pode ser estudado e preso pela ciência. Nós não podemos. A ciência é livre, mas não estuda os notáveis.

QUARTO ORADOR: Praticamente, o problema também é simples, é de qualificação. Precisamos estabelecer quem pode e quem não pode denunciar. Nós podemos. E assim como não votam, os incultos também não denunciam, porque lhes falta critério. Zelar pela limpeza mental da cidade é uma honra. Podemos transformá-la numa espécie de comenda, reservada aos que merecem. Criamos, por exemplo, a Ordem da Casa Verde, que terá o monopólio da delação legítima em Itaguahy.

PRIMEIRO ORADOR: Retomando o meu raciocínio, abominamos Bacamarte, mas precisamos dele. Abominamos a delação, mas precisamos dela. Formidável! Tudo ao contrário! (SCHWARZ, 1977, p. 50-51)

No entanto, a solução palaciana não só não se realiza, como aquece os ânimos da população da cidade. No banquete organizado para que Bacamarte firmasse o acordo, o alienista não se dispõe a flexibilizar suas teorias e um acidente inesperado (?) inviabiliza definitivamente o acordão vislumbrado. Encerrando a espiral de desacertos, "um bando mulambento" (conforme aponta a rubrica) entra em cena e rouba a comida do concilio de notáveis

Monta-se assim a outra possibilidade: a de uma solução popular. Em um primeiro momento, prepara-se o terreno cênico com um diálogo que demonstra o clima de tensão social externo ao palco, mas interno ao mundo da peça. No caso, um velho, de origem popular, por alguma razão, entra na assembleia de notáveis dizendo representar os desejos de fração dos trabalhadores:

VELHO: Burro. (Ao orador) Previno a casa de que esta minha implicância foi apenas pessoal. Quando um bem-nascido diz bobagem eu não resisto. Tenho esta fraqueza. Mas estou aqui a título de emissário, dos marceneiros e sapateiros, e contra o voto dos padeiros e ferreiros. Minha credencial (mostra). Nós achamos que é hora de uma ação conjunta. Os notáveis pegam o Bacamarte pelo pé, e nós passamos o dito-cujo pela guilhotina (SCHWARZ, 1977, p. 50).

Fica, então, explicitado que fora dali gestava-se uma revolta popular em reação aos desmandos de Bacamarte, chegando mesmo a inspirar certo medo na elite local ("Para mim isto cheira a pólvora. Eu vou para casa, enquanto estão desarmados" (SCHWARZ, 1977, p. 62)) que sabia reconhecer a necessidade de

[Notável:] depor Bacamarte, antes que o povo o derrube. Pois se a própria multidão depõe Bacamarte, parecerá que não precisam de nós. Podem pensar mesmo que não servimos para nada (SCHWARZ, 1977, p. 66)

Fracassada a solução pelo alto, é a rebelião popular que entra em cena. Deste ponto em diante, andamento formal da peça passa a ser dar com as lições epicizantes de Brecht ${ }^{15}$ : o levante se realiza dramaticamente por meio da narração das personagens que atuam como generalizações de classes e por diálogos cuja "argumentação excede a ação" (TELLES, 1998, p. 17).

No entanto, o que, bem ou mal, se resolve na forma, desanda no enredo. Ou o machadismo da peça subsume o princípio-Brecht. Se ao alemão, nada deve parecer impossivel de mudar, para Machado, tudo no Brasil parece rumar antes ao Nada do que à mudança. De modo que no contato com Machado, o épico do teatro brechtiano ganhava, assim, ares de tragédia

A primeira transição histórica à vista é, desde logo, posta a nu em seu caráter conservador. Neste caso, duas personagens fazem imagem de problema do conservadorismo modernizante da ciência: o professor alemão e suas amalucadas e patriarcais teorias sobre mulheres, e o próprio Bacamarte, cuja teoria pressupunha que negro não seria gente - para casos de negação disso, "sem trancar, sem pôr a ferro, não sara loucura nenhuma" (SCHWARZ, 1977, p. 27).

15 A revolta popular è tema dileto de Brecht, chegando o autor alemão mesmo a teorizar sobre as possibilidades estéticas de colocá-la em cena (1978) 
A solução dos notáveis, como já dito, é igualmente fracassada.

Em reação a estas, arma-se, então, uma guerra de classes pela hegemonia social do mundo de Itaguaí. Não sem as tentativas de contenção de certos atores sociais: Canjica ganha destaque no enredo justamente por ser um dos de baixo que se alçam a um papel de liderança e, nessa posição, procura atuar como um pelego entre os atritos de notáveis e populares. Agitando as massas e negociando com os de cima, Canjica é uma espécie de figuração de um populismo que não tem no horizonte a realização efetiva de um programa radical e popular; sua solução seria com "a câmara e o representante do povo, que sou eu. Em seguida governaremos em conjunto. Uma forma renovada de democracia" (SCHWARZ, 1977, p. 68).

De todo modo, a despeito da liderança conciliadora, a rebelião avança e chega mesmo a dar o seu passo mais fundamental: as forças de repressão tomam o lado dos rebeldes. Ocorre que ainda aí a negatividade do autor se faz presente e a coisa desanda novamente.

Do ponto de vista programático, a questão da escravidão retorna ao centro do palco e fica evidenciado que o limite daquela insurreição eram os bonecos da peça, ou melhor, a ideologia escravista:

BARBEIRO: Povo de Itaguahy! A nossa frente, histórica desde já, comporta no máximo escravistas de esquerda. Abolicionistas não. Quem falou? (Adianta-se um tipo, de punho erguido. O professor alemão vem por trás e amassa-lhe a cabeça). Dr. Bacamarte, lá para dentro. Logo falaremos (SCHWARZ, 1977, p. 68).

No mais, também a liderança popular trai os propósitos insurgentes e passa a negociar com Bacamarte, gerando uma fissura entre insurrectos. Aproveitando-se da divisão popular, Bacamarte e parte das forças repressivas armam uma "colossal trovoada" em que "na multidão, metade cai de costas, fulminada, a outra metade cai de joelhos, fazendo grandes mesuras. Os notáveis caem todos de joelhos, em sinal de afinação ideológica" (SCHWARZ, 1977, p. 74).

Ao fim, também a revolta resulta no Nada: o velho poderoso Bacamarte sai coroado de dentro da Casa Verde com o barbeiro preso ao seu lado, anunciando que:

Este é o momento culminante da história de Itaguahy: a entrada na idade moderna. Aplicaremos, sem desfalecimento, além de minha própria teoria, a teoria econômica do Padre Branquinho Teixeira Gonçalves, meu pranteado mestre e figura humana incomparável (SCHWARZ, 1977, p. 74).

Tem-se então instalada a vitória do Sistema Bacamarte, na qual um breve ato põe em sequências cenas fragmentadas que procuram condensar aspectos da vida social e ideológica do regime Bacamarte: relações amorosas entre um patrão e sua empregada doméstica que, apaixonada, delata o esquerdismo da esposa do primeiro; construção de uma imagem externa harmônica do país; capitulação de esquerdistas ao poder em curso; resoluta aplicação do princípio da passividade progressista por parte da elite; e anomia social.

Como se vê, a solução dos ricos e também a dos pobres são trabalhadas em chave paródica cujas resoluções desembocam em um lodo de impossibilidades de superação do previamente existente: os notáveis seguem sendo notáveis, os pobres seguem sendo pobres e mesmo o barbeiro Canjica, que tentou se alçar ao patamar de cima da estratificação social, volta ao seu lugar de origem. ${ }^{16}$ E claro, os bonecos seguem como bonecos. A tentativa de solução da elite desanda no banquete fracassado e a popular, ainda que dotada de maior complexidade, é igualmente malograda na impossibilidade de superação do escravismo e do populismo.

Assim, coincidentemente ou não, a peça acaba por se aproximar do Tropicalismo em eixos variados, ${ }^{17}$ dos quais destaca-se a crítica ao populismo e a conjugação estética do moderno e do arcaico

\footnotetext{
16 Vale destacar que a parodização do barbeiro Canjica guarda alguma singularidade crítica, uma vez que a critica ao populismo ainda engatinhava na intelectualidade artística de esquerda. Coincidentemente, Caetano Veloso foi outro que procurou caminhar nesse sentido, mas em rumo diverso: adotou a incorporação de modelos estéticos "populares" (no sentido de reverenciado pelas massas), não se atendo a um certo ideal de povo hipostasiado pela esquerda da época. Schwarz, por sua vez, viu no procedimento uma adesão a um liberalismo frágil, justo no auge da ditadura brasileira, que tivera início com o golpe militar de 1964.

17 Sérgio de Carvalho provocou Schwarz com tal similitude, questionando se "não há nessa peça certa atitude tropicalista, imagem
} 
como nó central de compreensão e intervenção artística do e no momento.

A diferença com a fórmula tropicalista seria que na peça o polo de modernidade seria um desejo (talvez impossivel) ainda a ser alcançado. Ao passo que no Tropicalismo, para Schwarz, haveria uma assunção gozosa dessa temporalidade acomodatícia como a do futuro que efetivamente havia chegado. ${ }^{18}$

De modo que o juizo de valor sobre o Tropicalismo que Schwarz ensaia neste momento é lastreado em certa normativa de incorporação artística do desejo político de uma "temporalidade superadora". Isso posto, não deixa de ser interessante que o motivo pelo qual o Tropicalismo atrai a atenção de Schwarz é também o motivo pelo qual ele se encanta por Machado: a formalização dessa combinação brasileira de elementos "antitéticos" e de temporalidades distintas. Sendo a postura diante desse relógio descompassado chamado Brasil, o critério de valor ao crítico na interpretação de Caetano Veloso e Machado de Assis - com vantagem para o segundo, é claro.

Condizente com esse desejo de defesa de uma temporalidade progressiva e cumulativa - ou, ao menos, a recusa categórica de seu contrário -, a peça se encerra com um gesto que procura se descolar de qualquer proximidade com uma espécie de anomia do desejo (ou mesmo gozo) diante da bárbara conjuntura política brasileira de então. Trata-se do curto e derradeiro capítulo da peça: o "Happy end", por sua vez, dividido em dois.

No primeiro happy end tudo se ajusta em favor dos notáveis e o sistema Bacamarte se desmonta por vontade do próprio alienista.

Ainda que para a elite, diante de seu "horror à violência entre brancos", fosse preferivel "dez Bacamartes a uma revolução", ao sistema Bacamarte faltava algo:
(Elegiaco) Mas vocês acham mesmo que nunca mais Itaguahy será uma grande família? Que não voltarão os dias festivos, quando opressores e oprimidos, fraternalmente, esperavam amanhã? [...] Mas então não vai sobrar nada? Eu só vou ganhar dinheiro? Assim eu não quero (SCHWARZ, 1977, p. 83).

E este "algo" é resolvido com uma nova virada na teoria da loucura de Simão, que resolve prender a si mesmo na Casa Verde:

TODOS: Não é possivel. Um milagre! É sublime. Vai ser tudo como antigamente! Voltaremos ao paternalismo e à bondade. Que felicidade! Viva Bacamarte! (Uníssono) Viva Simão Bacamarte! (SCHWARZ, 1977, p. 84).

De quebra, se regozijam ainda com uma

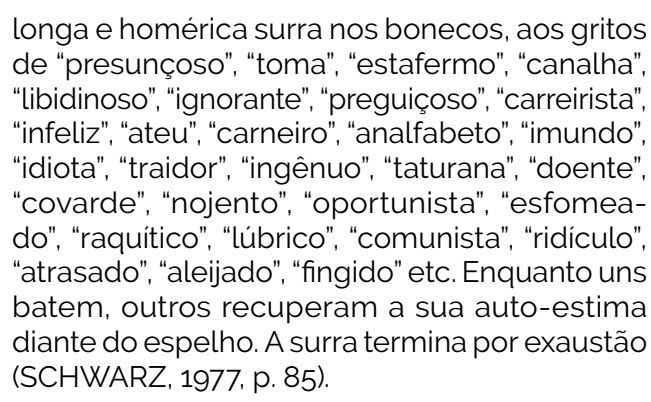

Pintado em chave ferina e em tom irônico, este primeiro happy end, no entanto, é prontamente seguido de um segundo, completamente descolado do andamento da peça. No instante realmente final da chanchada, quando um notável, depois de explicar ao público ter se tratado de "uma solução pouco provável, mas feliz" (SCHWARZ, 1977, p. 86), resolve dar ainda um último tapa em um dos bonecos antes de sair de cena, a composição cênica se altera e nota-se que, na realidade, o boneco é um homem!

Tem-se, então, o momento que o título é tornado concreto: diante do soco iminente do notável, o boneco tornado homem

apara com a esquerda e com a direita, aplica- lhe colossal bofetada, que lança o notável a

em que o lado do atraso se dá no plano do assunto crítico e o lado moderno em uma performatividade da linguagem? O maior dos críticos ao Tropicalismo - quando se torna artista - não é também um pouco tropicalista?" (CARVALHO apud SCHWARZ, [2014d]). Em resposta, Schwarz acata a sugestão de proximidade, mas ressalta a diferença no trato com a "combinação do moderno e do antigo". uma vez que ele teria procurado "explorá-la como problema, e não como uma essência nacional ou algo positivo", como teriam feito os tropicalistas em dado momento.

${ }_{18}$ Quase quatro décadas depois de suas primeiras críticas sobre o Tropicalismo, Schwarz retornou ao tema em novas chaves, menos refratária à fórmula, ainda que não menos critica à postura de Caetano Veloso: "sem prejuízo das convicções políticas contrárias do autor, o absurdo tropicalista formaliza e encapsula a experiência histórica da esquerda derrotada em 1964, e sua verdade" (SCHWARZ, 2012, p. 101). 
vinte metros, para dentro de um buraco sobre o qual está escrito em letras garrafais: A LATA DE LIXO DA HISTÓRIA. O boneco esfrega as mãos e vai para casa (SCHWARZ, 1977, p. 86).

Quanto ao segundo happy end, o próprio descolamento do mesmo em relação aos demais movimentos da peça é uma certa confirmação, talvez a contragosto do seu autor, das impossibilidades concretas de superação do que estava em cena, ao menos do ponto de vista da inteligência narrativa que organiza o material dramático da peça. Tornando-se nesse sentido igualmente um problema de forma de uma de imaginação que "balançava de um lugar para o outro e não produz nenhum resultado, não avança" (ARANTES, 2004, p. 284).

Ou ainda, a peça incorpora em sua forma algo que Paulo Arantes preferiu ter cuidado ao dizer sobre o Machado que se afigura em Schwarz: ali "no fundo, não há dialética", mas "alternância indefinida que não se resolve" (ARANTES, 2004. p. 284). Trocando em miúdos, como se no Brasil pós-golpe de Schwarz, Machado fosse mais "atual" do que Brecht.

A resolução do segundo happy end é o modo pelo qual o brechtianismo de Schwarz tenta se fazer presente, mas a relação tosca que estabelece com o restante da peça desmente sua própria verdade. Assim ele teria sentido antes pelo teor do gesto do que pelo que efetivamente se realiza.

O mesmo Arantes sugeriu que a "bofetada" seria a própria leitura schwarziana do Machado, em que se realiza a passagem ao primeiro plano da crítica que Machado fazia da elite, mas cujo decoro de homem público não the permitia pôr às vistas. Nesse sentido, seria um gesto machadiano por excelência, dispensando a discrição que seria necessária ao autor de O alienista.

Por outro lado, à mesma ocasião, também Schwarz comentou a respeito e assinalou que o segundo final feliz

é expressão de um desejo imaginário [...] e tira sua força da falta de verossimilhança [...].
O modelo é Brecht da Ópera dos três vinténs, onde o Mac Navalha está para ser enfocado e entra o cavalo alado da rainha e tira o Mac Navalha da forca para oferecer a ele um banco de presente (informação verbal). ${ }^{19}$

Procurando equalizar a dissonância, parece-me que o gesto final guarda, de fato, algo da dimensão desejante de Schwarz quanto ao presente de então, formando uma espécie de versão dramática do encerramento do ensaio "Cultura e política", quando evoca a luta armada via Quarup. Todavia, ainda que possa expressar algo da bofetada machadiana em relação à elite, ele se refere, sobretudo, a uma dimensão de desejo desarticulada do próprio conjunto apresentado, algo como um desejo recalcitrante de revolução em um cenário que nada leva a acreditar nessa possibilidade histórica. "Brecht eu misturo com Machado, e o meu samba vai ficar assim": de um lado um desejo de mudança revolucionária e de outro, um mundo em que tudo parece sempre levar ao Nada. ${ }^{20}$ Como se num mundo em que tudo parece solucionar-se em favor do poder ou do igual, o soco final fosse expressão de um desejo cuja realização só é possivel na chave do impossivel.

\section{Schwarz, Machado e dialética}

Ficássemos somente na inexistência de dialética no Machado de Roberto, a coisa já seria complicada. Afinal, como sugere Safatle, há algo

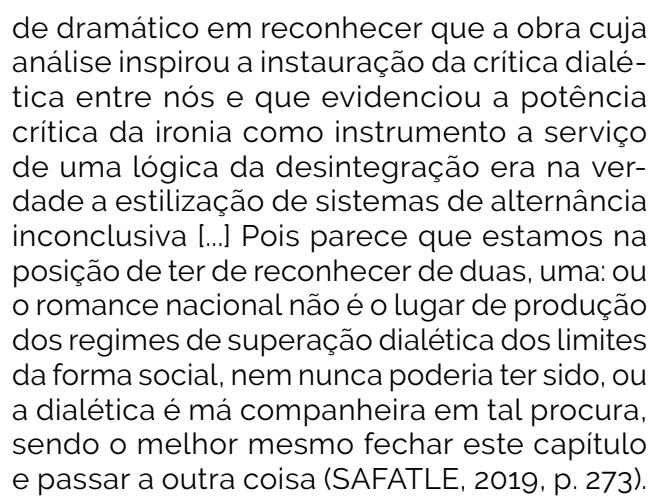

Há, porém, ainda um outro "drama" que atra-

\footnotetext{
19 Fala de Roberto Schwarz em evento-debate sobre A lata de lixo da história promovido em 28 de agosto de 2014 na Universidade de São Paulo.

20 Curiosamente, a mesma impossibilidade do soco quase foi alçada ao título, anos depois, de Um mestre na periferia do capitalismo:
} 
vessa o trabalho de Roberto Schwarz e vale ser comentado: repensar os bonecos. Ou ainda, repensar os escravos.

Na sua leitura posterior de Machado, há também algo da dimensão de movimentação/subjetividade impossivel dos bonecos da peça. O nó central do problema se encontra mais evidente no seu famoso ensaio "As ideias fora do lugar", em que o crítico procura compreender os mecanismos de aquilatação das ideias liberais em contexto brasileiro, de regime ostensivo de trabalho servil.

Do ponto de vista ideológico do problema, é interessante o modo como Schwarz procurou pensar essa convivência de contrários. Ele levanta que, nas condições oitocentistas brasileiras, a importação do liberalismo funcionava de modo desajustado em solo escravista. A fim de explicar o desajuste, procurou ver na relação estabelecida entre senhores de escravos e homens livres pobres a chave de compreensão. Neste quadro, "coube" às relações de favor a tarefa de equalizar órbitas distintas e, a priori, incompativeis.

Enquanto na Europa, o ideário liberal buscava dar conta de uma sociedade composta, de modo geral, por burgueses e proletários, no Brasil "encontrou" uma sociedade formada por três grupos sociais: o latifundiário, o escravo e o "homem livre pobre", ou "dependente". Sobre todos, "reinaria" o senhor de escravos. Seguindo Schwarz, no que diz respeito aos escravos, a relação de dominação e violência seria até formalizada (enquanto mercadorias que "eram"); quanto à multidão de homens livres que viviam em meio a uma sociedade cujo trabalho era feito por mãos negras, suas possibilidades de ganhos materiais pelo trabalho eram demasiadamente restritas, sobrando-lhes o favor dos senhores e pequenos golpes como forma social de sobrevivência. Resultando ao final um quadro de acomodações em que "o favor é, portanto, o mecanismo através do qual se reproduz uma das grandes classes da sociedade, envolvendo também outra, a dos que tem" (SCHWARZ, 2012, p. 16). Seria, portanto, da relação entre homens livres pobres e senhores que se equacionariam as contradições ideológicas entre as formas de vida do centro do capitalismo e da realidade periférica.

Dessa perspectiva, resulta uma visão de mundo que veria uma margem de arbitrio praticamente absoluta às elites, uma vez que todos estariam sob seu jugo: as pessoas livres sem propriedade the seriam dependentes e os escravizados seriam dominados por mecanismos de violência. $O$ apuro crítico e analítico de Schwarz é um feito e tanto. Com seu esquema crítico, ele é capaz de formular uma teoria que dê conta de explicar o funcionamento desajustado do liberalismo no Brasil, bem como o comportamento da elite local nestas condições:

Por que não seria - como era localmente
- respeitável e moderno um proprietário de
escravos na plenitude assumida de suas van-
tagens? [...] A ficção machadiana dá forma clara
à degradação causada à vida pelo funciona-
mento incompleto do padrão burguês no país,
e torna palpável, no mesmo passo, a folga e
plenitude possibilitadas por essa insuficiência
(SCHWARZ, 2000, p. 124,144).

Não obstante, se "torcermos" seu esquema interpretativo, o que se vê é também uma "jogada para debaixo do tapete" dos escravizados do esquema ideológico local. Bastaria apenas a coerção para efetivação da hegemonia escravista? No mais, tal modelo historiográfico, resulta, em termos culturais, numa interdição das próprias possibilidades de representação dessa larga fatia da população brasileira, uma vez que estariam fora do circuito ideológico-simbólico nacional. O que parece dizer mais sobre o ponto de vista do crítico do que sobre a História em si.

Em que medida a ideologia senhorial não

conforme depoimento de Paulo Arantes em evento-debate sobre A lata de lixo da história promovido em 28 de agosto de 2014 . na Universidade de São Paulo), por pouco, este não saiu como "O Nada na acepção brasileira do termo". Arantes ainda comentou que "Para Machado a modernização no Brasil não vai dar em nada, se não der em coisa pior. [...] No fim tem o soco do boneco porque o Roberto é de esquerda. [...] Mas no fundo o que ele acredita é que o Machado está certo. Só que isso, ele não pode traduzir em termos políticos. Então, o que ele faz? Uma peça de teatro, dá a entender nas entrelinhas dos seus textos pela mão de gato do Machado. Isso não pode ser traduzido em política. l... Essa tradição critica da qual o Machado é o pai-fundador acredita em governo, acredita que esse país é tocado por uma espécie de entropia social que tem a ver com acumulação e formação de valor, a função disso é você retardar a catástrofe final. Isto tem duas soluções: a revolução ou isso que está acontecendo no mundo, quando você vai segurando o dique" (informação verbal) 
acaba por ser replicada no próprio esquema ideológico que Schwarz propõe para a compreensão da vida social brasileira? Primeiro por aceitar sem maiores problemas o favor - ou seja, a relação mais simpática à elite local, afinal a escravidão era objeto de vergonha - como o nexo efetivo da nossa vida ideológica:

Sendo embora a relação produtiva fundamental, a escravidão não era o nexo efetivo da vida ideológica. A chave desta era diversa. [...] O favor é a nossa mediação quase universal - e sendo mais simpático do que o nexo escravista, a outra relação que a colônia nos legara, é compreensivel que os escritores tenham baseado nele a sua interpretação do Brasil, involuntariamente disfarçando a violência, que sempre reinou na esfera da produção (SCHWARZ, 2012, p. 15-17).

No mais, por compreender a relação entre senhor-escravo como resolvida na chave da pura violência e/ou consentimento praticamente total dos escravizados, uma vez que a "estabilidade lda relação escravista] não depende de assentimento subjetivo, mas de força bruta. A compensação imaginária, aqui, ainda quando existe, não constitui o cimento da ordem" (SCHWARZ, 2000, p. 161). A consequência dessa tomada de posição alinhada à visão de mundo dos senhores acaba engendrando uma interpretação da sociedade brasileira que "com um pouco de maldade, mas só um pouco", podemos dizer, figura uma vida social "apenas a partir dos desejos e do imaginário da casa grande. A ideologia senhorial se projeta sobre a realidade inteira, a fantasia dos senhores de criar um mundo ao seu talante" (CHALHOUB apud BERGAMINI; TIBURSKI; BITTENCOURT, [2009]). ${ }^{21}$

De sorte que, assim, é a própria dialética (e luta material entre as classes em âmbito local) que acaba por sair de cena. Como se no esquema proposto por Schwarz a dominação escravista não sofresse nenhuma resistência por parte de sujeitos escravizados e/ou dependentes, restando o arbitrio absoluto dos senhores diante da anuência servil dos dependentes e da chibata nos escravizados.
Voltemos à peça, sua crise formal e a bofetada derradeira: o gesto final que se procurou emular de Brecht é realizado no caso alemão por uma rainha, ou seja, uma personagem dotada de subjetividade no mundo criado na Ópera dos três vinténs. O responsável por pôr na lata de lixo da história o Brasil colonial é encenado na peça como um boneco, que faz par subjetivo com animais!

Essa diferença é fundamental e dá feição a um problema de forma para além das antinomias entre Machado e Brecht. O modo como a escravidão é trabalhada na obra de Schwarz encontra um ponto cego que tem relação com uma longa tradição historiográfica brasileira que tende a vê-los na chave da pura anomia ou objetos.

Nesse sentido, dialeticamente, onde a crítica de Schwarz avança em relação à crítica dos mecanismos de favor e do aproveitamento perverso que a elite fazia de ideias modernas em prol da perpetuação de práticas que seriam consideradas obsoletas, ela própria guarda um aspecto problemático justamente no ponto que não consegue ver movimento nas relações sociais em que escravizados estavam presentes.

Nesse sentido, a peça tem atualidade à medida que desvela que o complemento do espelho são as surras, cuja força crítica, aliás, se faz mais evidente hoje do que em outros tempos. Além disso, a própria crise estética a que está submetida, entre dois andamentos formais ligados a temporalidades distintas (Brecht e Machado), elucida os impasses da virada histórica, conceitual e política que o golpe de 1964 imprimiu a vários artistas e intelectuais animados pelos ventos mudancistas do momento anterior ao golpe, quando a sensação de país por decolar fazia-o "irreconhecivelmente inteligente" (SCHWARZ, 1977, p. 69). Como se a própria tentativa de equalizar o que parecia incompativel fosse antes marca de temporalidade-expectativas em disputa histórica do que propriamente uma idiossincrasia estética de um jovem marxista encantado por Brecht e Machado.

${ }_{21}$ Fundamental levar em conta que o que está sendo posto em jogo não é uma crítica pura e simples do trabalho de Roberto Schwarz. Muito pelo contrário, trata-se de levantar como mesmo um dos mais radicais críticos literários e marxistas em atividade acabou por replicar em seu esquema interpretativo um movimento ideológico da própria classe que procurava criticar. Nesse sentido, menos do que uma fraqueza do crítico, fica evidente a dimensão da profunda força que a hegemonia senhorial exerce em nossa vida intelectual. 
Por outro lado, a questão dos bonecos revela também - provável que hoje igualmente com mais nitidez ${ }^{22}$ - uma faceta problemática do trabalho do autor: os escravos, figurados na peça como bonecos, só ganham subjetividade e atuação política na ordem do impossivel.

\section{Caras pálidas, bonecos negros ${ }^{23}$}

Neste ponto, estamos, portanto, diante de alguns problemas da maior importância quanto ao que constitui uma certa teoria da História que estrutura o pensamento schwarziano. De forma bastante resumida e pensando na sua feição brasileira e contemporânea, o que se arma é o seguinte: diante dos impasses estruturais de modernização que remontam desde a colônia e seu respectivo sentido histórico, "a nação não vai se formar, as suas partes vão se desligar umas das outras, o setor 'avançado' da sociedade brasileira já se integrou à dinâmica mais moderna da ordem internacional e deixará cair o resto" (SCHWARZ, 2014a, p. 57) - sendo a referência de "resto" justamente os bonecos que outrora foram negros escravizados, aos quais a construção de hegemonia não dependeria de nenhum consentimento, mas pura coerção. Feita a abolição, estes se teriam se tornado ex-escravos abandonados à sua sorte e, depois do colapso da modernização brasileira, irrealizada a integração nacional-desenvolvimentista dos mesmos, restariam por aí como "sujeitos monetários sem dinheiro, ou de ex-proletários virtuais, disponiveis para a criminalidade e toda sorte de fanatismos" (SCHWARZ, 2014a, p. 160).

No centro do problema encontra-se uma noção de dialética em grande medida sustentada por uma noção de agência das classes populares cuja realização só seria possivel se mediada pela atua- ção em conjunto com certa intelectualidade. Não por acaso, tanto em relação aos ex-escravos como aos sujeitos monetários sem dinheiro, encontra-se um fundo comum de pessoas ao dispor da sorte, do acaso e/ou de aproveitadores. Para o crítico, o "avanço social" no Brasil se daria, portanto, na mediação calculada entre um agente da reflexão intelectual e a força bruta da massa popular, a qual o método de alfabetização de Paulo Freire seria o exemplo modelar. Afinal, no método estariam

o arcaismo da consciência rural e a reflexão especializada de um alfabetizador; entretanto, a despeito desta conjunção, nada menos tropicalista do que o Método. Por quê? Porque a oposição entre os seus termos não é insolúvel: pode haver alfabetização (SCHWARZ, 1978, p. 76).

Mas, como o próprio Schwarz disse a respeito do filme Os fuzis (1964), tendo em vista que no Brasil "a massa fermenta, mas não explode", sua produção intelectual acaba por aproximar-se de uma concepção de História cujo foco incide sobretudo na crítica e "constatação da margem de liberdade absurda e antissocial de que a classe dominante dispõe no país" (SCHWARZ, 2014, p. 102).

Não se trata aqui de negar, em absoluto, a centralidade da escravidão e suas continuidades como o elemento estrutural de maior centralidade na História brasileira. Muito pelo contrário, ela constitui, sim, o cimento da ordem. Ocorre que há maneiras e maneiras de pensá-la. Schwarz, nesse sentido, se filia a uma tradição bastante importante do pensamento dialético brasileiro cuja reflexão sobre a escravidão está fortemente assentada na compreensão do processo histórico a partir de uma noção econômica do processo. Ou seja, uma noção que põe centralidade no sentido colonial da instituição, pensando-a em termos de produtividade econômica e vinculada a um tempo histórico pretérito.

\footnotetext{
22 Qual seria a reação do público em relação aos bonecos caso a peça tivesse tido mais circulação? Em um periodo mais ou menos contemporâneo à reedição do texto, duas peças exibidas em São Paulo foram alvo de debates por conta de representações de sujeitos negros: "Entrevista com Stela do Patrocínio" em 2017 e "A mulher do trem" em 2015. A primeira por ter uma atriz branca representando uma figura histórica negra e a segunda pelo uso de blackface. Qual seria a recepção de sujeitos históricos negros representados como bonecos que só apanham?

${ }_{23}$ "Um movimento importante da vida intelectual brasileira de 30 para cá que foi a de dizer que a questão no Brasil não é uma questão de raça, pois a questão de raça é uma questão que nos inferiorizava historicamente como raça inferior; a questão é de classe: brancos e negros estão igualmente sujeitos ao capital embora seja raro, existem também capitalistas negros, pois a questão é de posição no processo social. Essa foi uma tese muito importante no Brasil progressista dos anos 30 e hoje está em recuo acelerado porque com a coisa do multiculturalismo, nós embarcamos novamente na ideia de que a diferença racial é que define o pais e não a estrutura econômica: aqui se trata de um forte retrocesso" (SCHWARZ, 2009, p. 185).
} 
Ora, não só parte importante da historiografia mais recente tem levantado um aspecto da maior importância quanto ao caráter essencialmente moderno da segunda escravidão, ${ }^{24}$ como tem sido mais e mais debatido o aspecto moderno também das lutas levadas a cabo por escravizados. ${ }^{25}$

No mais, uma noção da ordem social em que os escravos possam ser figurados como bonecos que somente apanham e nada mais, para além de deixar escapar uma interdependência dialética entre lutas escravas e acentuação das contradições do regime escravista - justamente porque concebe tal força "como termo morto ou negativo" -, está também perigosamente próxima a uma noção senhorial de mundo em que o Eu (senhor) não consegue conceber um Outro (escravizados e pobres livres) fora de uma verticalidade hierárquica que tem a si mesmo como polo dominante; ou ainda, em que o Outro, "fora dos referenciais da verticalidade, haveria apenas pulverização, átomos sem existência social" (CHALHOUB, 2003, p.60-61). ${ }^{26}$

Ou conforme o próprio procurou explicar:

A ideia dos bonecos era apresentar um plano abaixo da luta de classes, como ela aparece politicamente. É, naturalmente, calcado na escravidão. Basicamente, é de que a luta política se faz num nível, e ainda abaixo desse nível tem um pessoal que leva pancada e pronto. O final da peça é a ideia que esse pessoal que leva pancada em baixo, levanta e dá um revide (informação verbal). ${ }^{27}$
No caso de A lata de lixo da história, uma composição cênica realizada a partir de bonecos representando os escravos diz algo da visão schwarziana sobre os sentidos do escravismo, da luta de classes no Brasil oitocentista e da noção de sujeito histórico.

Assim, não deixa de ser interessante que em um debate promovido em 2014 sobre a atualidade da peça, mais de uma questão foi direcionada quanto ao lugar contemporâneo dos bonecos. Muito se falou sobre quem seriam os bonecos (falou-se em pixuleco, sujeitos periféricos, PCC etc.) ou mesmo de sua efetiva atualidade à luz do que seria a "formação dos sujeitos periféricos". A resposta talvez seja em outra direção: os bonecos não seriam o ponto cego cujo sentido a ser extraido e trabalhado é antes o de sua faceta problemática do que de seu possivel acerto?

\section{Referências}

ARANTES, Paulo. Sentimento da Dialética. Rio de Janeiro: Paz e Terra, 1992.

ARANTES, Paulo. Providências de um crítico literário. In: ARANTES, Paulo; ARANTES, Otilia. Sentidos da formação. Rio de Janeiro: Paz e Terra, 1997. p. 7-66.

ARANTES, Paulo. Zero à esquerda. São Paulo: Conrad Editora do Brasil, 2004.

\footnotetext{
24 Conforme aponta Dale Tomich: "o significado sistêmico da escravidão transformou-se com a emergência da relação capital-trabalho assalariado no decurso do século XIX. Os produtos da mão-de-obra escrava entraram diretamente no consumo da classe trabalhadora assalariada europeia, numa escala crescente. Foram importantes como meio para manter a relação de troca entre trabalho assalariado e capital, e também contribuiram diretamente para reduzir o custo de reprodução da mão-de-obra assalariada. Ȧ medida que a relação capital-trabalho assalariado ia se tornando largamente estabelecida, foi emergindo um imperativo sistêmico, no sentido de aumentar a mais-valia mediante a redução do valor da mão-de-obra, o que, por sua vez, requeria produtores escravizados para fornecer bens cada vez mais baratos para o consumo da classe trabalhadora" (TOMICH, 2011, p. 96-97). De modo que quando a escravidão passa a ser um dos mecanismos centrais da produção moderna de mais-valia e de acumulação primitiva de um capitalismo globalizado, ela passa a ser conceituada como "segunda escravidão".

25 Provavelmente tomando o trabalho de E.P. Thompson como referência, Paul Gilroy sugere, por exemplo, que não é de menor importância que "ao final do século XVIII um quarto da marinha britânica era composto de africanos para os quais a experiência da escravidão fora uma poderosa orientação rumo às ideologias de liberdade e justiça", enraizando, portanto, ideologias radicais anteriores à instituição do sistema fabril em uma "cultura maritima insubordinada dos piratas e outros trabalhadores pré-industriais do mundo" (GILROY, 2001, $\mathrm{p}$. 54). De um ponto de vista mais local, focando no caso brasileiro, Clóvis Moura argumenta, por exemplo, que até meados do século XIX foram somente os escravos que, efetivamente, combateram o regime escravocrata. De forma que tais lutas "formaram um dos termos de antinomia dessa sociedade. Mas não formaram apenas um dos termos dessa antinomia: foram um dos seus elementos dinâmicos porque contribuíram para solapar as bases econômicas desse tipo de sociedade. Criaram as premissas para que, no seu lugar, surgisse outro: [...] as lutas dos escravos, ao invés de consolidar, enfraqueceram aquele regime de trabalho, fato que, aliado a outros fatores, levou o mesmo a ser substituido pelo trabalho livre" (MOURA, 1988, p. 269).

26 De resto, o próprio marxismo, por muito tempo, teve dificuldade em compreender as lutas escravas "como algo significante, uma vez que, em sua concepção etapista da história, a escravidão - não importando o quão contemporânea - era vista como uma instituição pré-moderna, banida da história e relegada ao passado" (BUCK-MORSS, 2011, p. 145).

27 Fala de Roberto Schwarz em evento-debate sobre A lata de lixo da história promovido em 28 de agosto de 2014 , na Universidade de São Paulo.
} 
ARRUDA, Maria Arminda do Nascimento; VILLARINO, Leandro Vizin. O conceito de formação em tempos críticos: esboço de reflexão. In: $40^{\circ}$ ENCONTRO ANUAL DA ANPOCS. Anais [...]. São Paulo: ANPOCS, 2016. Disponivel em: http://www.anpocs.com/index.php/ encontros/papers/40-encontro-anual-da-anpocs/ st-10/st22-6/10363-o-conceito-de-formacao-em-tempos-criticos-esboco-de-reflexao. Acesso em: 10 fev. 2021.

BERGAMINI, Atilio; TIBURSKI, Eliete Lucia; BITTENCOURT, Icaro. Entrevista com Sidney Chalhoub. AEDOS, Porto Alegre, v. 1, n. 1, 2009. Disponivel em: https:// seer.ufrgs.br/aedos/article/view/9823/5628. Acesso em: 10 fev. 2021

BRECHT, Bertolt. Estudos sobre teatro. Rio de Janeiro: Nova Fronteira, 1978.

BUCK-MORSS, Susan. Hegel e Haiti. Novos estudos CEBRAP, São Paulo, v. 30, n. 2, 2011. Disponivel em: https://www.scielo.br/j/nec/a/Rms6hs73V39nPnYsv44Z93n/?lang=pt. Acesso em: 10 fev. 2021.

CARDOSO, Fernando Henrique. Empresário industrial e desenvolvimento econômico. São Paulo: Difel, 1964.

CHALHOUB, Sidney. Machado de Assis historiador. São Paulo: Companhia das Letras, 2003.

DEBATE A lata de lixo da história (Roberto Schwarz). [S. l.: S. n.], 2014. 1 video (118 min). Publicado pelo canal César Marins. A LATA DE LIXO DA HISTÓRIA (ROBERTO SCHWARZ), 06/08/2014, São Paulo, USP. Disponivel em: https://www.youtube.com/watch?v=1B47KRaJIJo\&ab_channel=CésarMarins. Acesso em: 20 jul. 2021.

GILROY, Paul. O Atlántico negro: modernidade e dupla consciência. São Paulo: Editora 34; Rio de Janeiro: Universidade Cândido Mendes, Centro de Estudos Afro-Asiáticos, 2001.

MOURA, Clóvis. Rebeliões da Senzala. Porto Alegre: Mercado Aberto, 1988.

MUSSE, Ricardo. Poeta, o lado quase desconhecido do crítico literário Roberto Schwarz. Folha de S.Paulo, São Paulo, ano 97, n. 32.258, 28 jul. 2017. Caderno Ilustríssima. Disponivel em: https://Www1.folha.uol.com.br/ ilustrissima/2017/07/1905026-poeta-o-lado-quase-desconhecido-do-critico-literario-roberto-schwarz. shtml. Acesso em: 12 jul. 2021.

PASTA, José Antonio. Pensamento e ficção em Paulo Emilio. In: GOMES, Paulo Emilio Sales. Três mulheres de três PPPês. São Paulo: Companhia das Letras, 2015.

QUERIDO, F. M. Nacional por negação: ensaio e "crítica independente" no último Roberto Schwarz. Revista do Instituto de Estudos Brasileiros, [S. l.], n. 74, p. 233-249, 2019. Disponivel em: https://www.revistas.usp.br/rieb/ article/view/164971. Acesso em: 20 jul. 2021.

REIMBERG, Mauricio. A critica de Roberto Schwarz (1958-1968). São Paulo, 2019. Tese (Doutorado em Teoria Literária e Literatura Comparada) - Universidade de São Paulo, São Paulo, 2019.
ROBERTO Schwarz em 1968: A lata de lixo da história. IS. l.: s. n.], 2014. 1 video (152 min). Publicado pelo canal STI FFLCH USP. Disponivel em: https://www.youtube.com/ watch?v=m_nt51WgT-o\&ab_channel=STIFFLCHUSP. Acesso em: 20 jul. 2021.

RODRIGUES, José Albertino. Sindicato e Desenvolvimento no Brasil. São Paulo: Difusão Européia do Livro, 1968.

SAFATLE, Vladimir. Dar corpo ao impossivel. São Paulo: Autêntica, 2019.

SCHWARZ, Roberto. A lata de lixo da história: farsa. Rio de Janeiro: Paz e terra, 1977.

SCHWARZ, Roberto. O pai de família e outros estudos. Rio de Janeiro: Paz e terra, 1978.

SCHWARZ, Roberto. Um mestre na periferia do capitalismo. São Paulo: Companhia das Letras, 2000.

SCHWARZ, Roberto. Que horas são? São Paulo: Companhia das Letras, 2006.

SCHWARZ, Roberto. Dialética da formação. In: PUCCI, B. et al. Experiência formativa e emancipação. São Paulo: Nankin, 2009.

SCHWARZ, Roberto. Ao vencedor as batatas. São Paulo Duas cidades: Editora 34, 2012.

SCHWARZ, Roberto. Martinha versus Lucrécia. São Paulo: Cia. das Letras, $2012 a$.

SCHWARZ, Roberto. Sequências brasileiras. São Paulo: Companhia das Letras, 2014a.

SCHWARZ, Roberto. A lata de lixo da história: chanchada política. São Paulo: Companhia das Letras, 2014b.

SCHWARZ, Roberto. A LATA DE LIXO DA HISTÓRIA Prefácio inédito a uma chanchada de 1968. Revista Piaui. v. 91, p. 68-69, abril 2014c. Disponivel em: https://piaui. folha.uol.com.br/materia/a-lata-de-lixo-da-historia. Acesso em: 20 jul. 2021.

SCHWARZ, Roberto. A Lata de Lixo da História: Chanchada Política Conversa com Roberto Schwarz. Revista terceira margem, Rio de Janeiro, v. 18, n. 30, ano XVIII, jul./dez. 2014d. Disponível em: https://revistas.ufrj.br/ index.php/tm/article/view/9757/7574. Acesso em: 20 jul. 2021.

SÜSSEKIND, Flora. Papéis colados. Rio de Janeiro: Ed. UFRJ, 1993.

TEIXEIRA, Ivan. Irônica invenção do mundo: uma leitura de O Alienista. Revista USP, São Paulo, n. 77, p. 149-169, 2008. Disponivel em: https://www.revistas.usp.br/ revusp/article/view/13663. Acesso em: 26 jul. 2021.

TELLES, Renata. A colaboração de Roberto Schwarz em Almanaque. Boletim de Pesquisa NELIC, Florianópolis, v. 3. p. 15-20, 1998.

TELLES, Renata. Roberto Schwarz vai ao cinema: imagem, tempo e política. Tese (Doutorado em Teoria Literária). UFSC, Florianópolis, 2005. 
Fernando Cambauva Breda

Mestre em Teoria e História Literária pela Universidade

Estadual de Campinas (UNICAMP), em Campinas, SP, Brasil.

\section{Endereço de correspondência}

Fernando Cambauva Breda

Universidade Estadual de Campinas

Rua Sérgio Buarque de Holanda, 571

Cidade Universitária, 13083-859

Campinas, SP, Brasil

Os textos deste artigo foram revisados pela Poá Comunicação e submetidos para validação do autor antes da publicação. 